\title{
Trace metal concentration in atmospheric aerosols in some city areas of Bangladesh
}

\author{
M. N. Mondol ", M. Khaled, A. S. Chamon and S. M. Ullah \\ Department of Soil, Water and Environment, University of Dhaka, Dhaka-1000, Bangladesh.
}

\begin{abstract}
Aerosol particulate matter and trace gases were sampled at five locations in the city areas of Bangladesh. The sampling sites were selected in the city areas near motor vehicles run with heavy traffic. The average concentrations of total suspended particulate matter in city ambient air were 413.02, 292.63, 671.65, 184.09 and $301.13 \mu \mathrm{g} \mathrm{m}-^{3}$ in Dhaka, Noakhali, Chittagong, Faridpur and Kustia, respectively, which were higher than the daily average value, given by WHO and US EPA standard. The highest SPM concentration is in Chittagong (671.65 $\left.\mu \mathrm{g} \mathrm{m}^{-3}\right)$ and the lowest in Faridpur $\left(184.09 \mu \mathrm{g} \mathrm{m}^{-3}\right)$. The city areas studied fall in the 'Unhealthy" to "Extremely Unhealthy' class according to the Air Quality Index, 2003. Trace metal concentrations of total suspended particulate matter in city ambient air were analyzed. The reported previous $\mathrm{Pb}$ concentration in farmgate, Dhaka was $1238 \mathrm{ng} \mathrm{m}^{-3}$ by Biswas et al., (2003) and now shows a decreasing tendency, presumably due to the ban on the use of leaded fuel. The average results of trace metals have been compared to national and international standards. The $\mathrm{Cu}$ and $\mathrm{Zn}$ concentration of current study is found very high in comparison with other previously reported results. The air of Chittagong city is highly polluted. Motor vehicles, especially two stroke engine vehicles are increasingly major sources of air pollution in Chittagong.
\end{abstract}

Key words: Aerosol; Trace Metals; Suspended Particulates Matters; City Areas

\section{Introduction}

Urbanization, industrialization and economic growth resulted in a profound deterioration of urban air quality (Wahid, 2006). Modernization and enhanced industrial activities led to the increased use of fossil fuels and their derivatives, particularly in developing countries like Bangladesh. Concern about atmospheric particulate pollution in urban region is receiving growing importance worldwide. Urban areas are mainly affected by suspended particles, which pose a serious risk to human health (Wahid, 2006). Both natural and human processes contribute to their concentrations (Ramanathan and Crutzen, 2003). In recent years, air pollution has emerged as a serious environmental issue, mainly due to the presence of toxic metals in the atmosphere as a consequence of rapid industrialization and increased transportation (Borbely-kiss et al., 1999). It is understood that aerosol particulate matter has a correlation with toxic trace metals and affects human health in urban and rural environments (Begum et al., 2013).

Trace metals pollution in the atmosphere is mainly related to the inorganic fraction, which is released from various kinds of vehicles, brickfields, constructions, tanneries, navigation, corrosion of metallic parts, soil dusts, etc., (Salam and Salam, 2011). Trace metals like arsenic, cadmium, chromium, cobalt, copper, lead, mercury, manganese, nickel, vanadium and zinc along with many other elements were found in the ambient air of Dhaka city (Borbely-kiss et al., 1999). Bangladesh Atomic Energy Commission (BAEC) (Khaliquzzaman et al., 1997) reported $463 \mathrm{ng} \mathrm{m}-3$ lead in Dhaka air during the dry months in 1997. For mega cities in India and Pakistan high exceedance of the WHO guideline values for cadmium and lead were reported (Sharma and Patil, 1992; Smith et al., 1996).

Air quality (AQ) data in the country is available for the capital city, Dhaka. Results of monitoring in other cities are still limited. The sampling sites were selected in the city areas near motor vehicles run. Here we report the occurrence and characteristics of total suspended particulate matters (SPM) and also airborne heavy metal concentrations lead $(\mathrm{Pb})$, cadmium $(\mathrm{Cd})$, copper $(\mathrm{Cu})$ and zinc (Zn) from October to December, 2011, in five cities in Bangladesh.

\section{Materials and methods}

\section{Sampling of Atmospheric Particulate Matter:}

Aerosol samples were collected by a set of low volume samplers with open face heads. The sampling head was placed at least $3 \mathrm{~m}$ above the ground with the intakes facing 
downward. For protection from rains, unacceptable wastes or water the sampling heads were situated under shelters made from $10 \mathrm{~L}$ polyethylene-buckets, which were mounted on a pile with the open side down. Polyethylene was chosen, as it contains no plasticizers, thus, no contamination with respect to inorganic aerosols was found. Sampling periods were fixed $8 \mathrm{~h}$ (daytime) with sampler changes at approximately 8:00 to $16: 00 \mathrm{~h}$. The sampler was supported with the quartz fiber filters (Gelman, Membrane Filters, Type TISSUQUARTZ 2500QAT-UP, $47 \mathrm{~mm}$ diameter) applying an averaged sampled air volume of $13.13 \mathrm{~m}^{3}$. Sampling was performed $3 \mathrm{~m}$ above ground with open face filter sampling heads faced downwards, thus yielding an aerosol fraction equivalent to "total suspended particles" (TSP). Field Blanks were determined for each sampling site and considered for the calculation procedures. The loaded filters were stored in clean Millipore Petridishes and kept under refrigeration.

\section{Site description:}

The samples were collected during October to December of 2011. A total of five districts were selected for collecting air particulate samples for the experiment. The atmospheric particulate matters were collected from single place in Dhaka (Farmgate), Noakhali (Karachi bazar), Chittagong (Khulshi), Faridpur (Faridpur medical college) and Khushtia (Daulotpur). The sampling sites were selected in the city areas near motor vehicles run road. Each sample were collected in three replications. The laboratory analyses were conducted in the department of Soil, Water and Environment, University of Dhaka.

\section{Atmospheric Particulate Matter Analysis:}

The mass of suspended particulate matter was determined from the initial and final weight of the dust Cup Vail. Samples were transported from the sampling sites to the laboratory and kept in a refrigerator until analysis to minimize volatilization. Blank correction was performed by preparing field blanks using the same procedure as that for the SPM samples. The particulate matters were digested with aqua regia $\left(1 \mathrm{HNO}_{3}: 3 \mathrm{HCl}\right)(\mathrm{V} / \mathrm{V})$. The samples were kept overnight with aqua regia $(25 \mathrm{~mL})$ before digestion. On the following day the samples were digested in digestion chamber. After completion of digestion, the particulate matters were transferred into solution with distilled water and diluted to $25 \mathrm{~mL}$ in volumetric flasks. Then the solutions were preserved in the laboratory for analyses. Before atomic adsorption analyses, the samples were filtered with Whatmann paper no. 40. The whole PTFE membrane filters were extracted with $25 \mathrm{~mL}$ of concentrated aqua regia $1 \mathrm{HNO}_{3}: 3 \mathrm{HCl}(\mathrm{V} / \mathrm{V})$ about 120 minutes in digestion chamber and then analyzed for the trace elements. Lead, Cadmium, Copper and Zinc were determined by Atomic Absorption Spectroscopy (AAS). Calibration was done with three standard solutions of different concentrations.

\section{Results and discussion}

The concentration of atmospheric particulate matter commonly known as suspended particulate matter (SPM) was determined in the laboratory and compared to the standard value. The atmospheric particulate matters were collected from single place in Dhaka, Noakhali, Chittagong, Faridpur and Khushtia. The sampling sites were selected in the city areas near motor vehicles run road.

\section{Average total suspended particulate matter (SPM):}

The average concentration of total suspended particulate matter in city ambient air were 413.02, 292.63, 671.65, 184.09 and $301.13 \mu_{\mathrm{g} \mathrm{m}}{ }^{-3}$ in Dhaka, Noakhali, Chittagong, Faridpur and Kustia, respectively (Table I), which were higher than the daily average value, given by WHO and US standard. The highest SPM concentrations were in Chittagong (671.65 $\mu \mathrm{g} \mathrm{m-3}$ ) and the lowest in Faridpur district $\left(184.09 \mu \mathrm{g} \mathrm{m} \mathrm{m}^{3}\right)$. The SPM concentration were significantly different in five locations. The concentration of total suspended particulate matter in air in descending order is as follows: Chittagong > Dhaka $>$ Kustia> Noakhali>Faridpur

Considering total SPM value in city air, Chittagong, Dhaka and Kustia are in the 'extremely unhealthy class', Noakhali in 'very unhealthy' and Faridpur in 'unhealthy class' described in Air Quality Management Project (2003) (Table II). The higher value of total suspended particulate matter (av. conc.) in Dhaka city ambient air (in 2008) was $385.3 \mu \mathrm{g}$ $\mathrm{m}^{-3}$ as reported by Rahman and co-workers (Rahman et al., 2013). The World Bank and Department of the Environment of Bangladesh found SPM concentrations of 665-2456 $\mu \mathrm{g} \mathrm{m}^{-3}$ at Farmgate, Dhaka (Core, 1998) based on 8-h measurements at several locations along busy roads in Dhaka city. The difference between these results and those of the present study indicates that the ambient concentrations of SPM in Dhaka are decreasing remarkably. However, the measurements showed that the daily average (8-h daily) concentration of SPM was 413.02 $\mu \mathrm{g} \mathrm{m} \mathrm{m}^{3}$ at farmgate area, Dhaka, in October to December, 2011. The cause of this decreasing concentrations may be due to the positive initiatives and steps taken by the government and some non-government agencies in reducing vehicular emission by banning 2 -stroke 
tri-wheeler and replaced them with 4-stroke CNG driven tri-wheeler in 2002. This action has significantly improved the Dhaka city air quality, but still the ambient air quality fails to meet the WHO standards (Ahammad et al., 2010, Anomymous, 2005). The causes of higher value of SPM in the air of Dhaka city are incomplete combustion of fossil fuel used by different types of vehicles. Railway engines, industrial plants, power plant, brick kilns, open burning incineration, solid waste disposal sites, road side dust particles, road diggings, constructions, long-range transport and other development activities are also contributing to the higher value of SPM in Dhaka (Salam et al., 2008).

Air Quality Index (AQI) proposed in "country synthesis report on urban air quality management, Bangladesh," (Anomymous, 2003) is presented in Table II. The highest suspended particulate matter (SPM) was measured in traffic location in ambient air of Chittagong city in this study which is in the extremely unhealthy class (Table II). The similar results were also reported earlier by many investigators (Anomymous, 2006; Jamaluddin et al., 2012; Jamaluddin and Khorshed, 2012). The city areas like Bogra, Rajshahi, Sirajgong and Pabna studied before by ADB (Anomymous, 2006) also falls in the 'extremely unhealthy' class (Table II) (AQMP, 2003).

The worst pollutants that affecting the megacities as a whole are suspended particulate matter (SPM), particularly amongst mega cities in the continent of Asia. The sources of SPM are varied and can include natural sources such as wind blown dust from desert areas and the generally more toxic SPM from man made sources such as power generation, motor vehicles (particularly diesel) and industrial processes. Air pollution in Chittagong is serious due to increasing population and associated motorization. Severe air pollution is threatening for human health and economic growth in Chittagong. In Chittagong city, air pollution is worsening rapidly due to upward trends in vehicle ownership and use, particularly two stroke engines, vehicles. SPM pose significant air pollution problems, and have major public health impacts. In particular, SPM level in Chittagong ranges from 2 to 4 times higher than Bangladeshi standard, but 12 times greater than WHO guidelines in the most heavily polluted commercial locations in Dhaka. The SPM in air of Chittagong city is higher than that of TLV $(500 \mu \mathrm{g} / \mathrm{m} 3)$ recommended by WHO and more than 3 times higher than the DoE standard (200 $\mu \mathrm{g} / \mathrm{m} 3)$.

Three wheeler vehicles with two stroke engines have already been withdrawn from the city roads to protect the urban environment. These three wheeler vehicles were responsible for maximum (around 60\%) air pollution in the city. In fact, these three wheelers were popular vehicles among the middle class and upper middle class people/societies of Chittagong city. By this time government of Bangladesh has imposed a ban on this two stroke three wheelers and invited compressed natural gas (CNG) vehicles to replace two stroke vehicles. As a result of which, the city and the urban dwellers got rid of around $60 \%$ of air pollution by this time (Ahmed, 2006).

\section{Lead $(\mathrm{Pb})$ concentration:}

The $\mathrm{Pb}$ concentration in air (total SPM) varied from 95.2 (Noakhali and Faridpur) to 485 ng m- $^{3}$ (Farmgate, Dhaka) (between October to December 2011) in different city areas in Bangladesh during the dry months (Table II). The $\mathrm{Pb}$ concentrations in SPM of the ambient air were 485, 95.2, 152.3, 95.2 and $258.9 \mathrm{ng} \mathrm{m}^{-3}$ in Dhaka, Noakhali, Chittagong, Faridpur and Kustia, respectively (Table III). The average $\mathrm{Pb}$ concentration in air varied from 51 (Jahangirnagar University, Savar) to 335 (BCIC Bhaban, Motijheel) $\mathrm{ng} \mathrm{m}^{-3}$ as reported by Salam et al., (2008). The higher value of $\mathrm{Pb}$ in air may be due to the presence of heavy traffic at the Farmgate area, while the lower value may be due to relatively lower level of traffic. The level of $\mathrm{Pb}$ in rural areas in Bangladesh was found to be below the detection limit (Salam et al., 2003).

We found the concentration of $\mathrm{Pb}$ at the five city areas is lower than the WHO 1999 guideline value of $500 \mathrm{ng} \mathrm{m}^{-3}$ for urban areas. Scientists at the Bangladesh Atomic Energy Commission (BAEC) observed that Dhaka was the most $\mathrm{Pb}$-polluted city in the world during the year of 1996. A 17-month survey conducted by the scientists of BAEC detected $465 \mathrm{ng}$ m-3 Pb for PM2.5 in Dhaka city air during the dry months (between November and January 1996) (Khaliquzzaman et al., 1997). According to Biswas and co-workers (Biswas et al., 2003) and Begum and co-workers (Begum et al., 2013) higher $\mathrm{Pb}$ concentration in Dhaka city air in SPM was reported and which was above the WHO standard value (Table III). The total average concentrations of $\mathrm{Pb}$ in PM2.5 was $204 \mathrm{ng}$ m-3 in different locations in Dhaka city reported earlier (Salam et al., 2008). However, the atmospheric $\mathrm{Pb}$ concentration in Dhaka is decreasing gradually, presumably due to the ban on leaded gasoline in Bangladesh, although it is still higher than that found in European cities (Puxbaum, 2001) and cities in USA (Table III). However, it is lower than that reported for Southeast Asian sites such as Laore, Pakistan (3920 ng m-3) (Smith et al., 1996) and Calcutta (6630 ng m-3), (Chatterjee et al., 1988), Bombay (550 ng m-3) (Sharma and Patil, 1992), India. 
Cadmium (Cd) concentration:

The daily average concentration of $\mathrm{Cd}$ in atmospheric aerosol in different city areas were 8.60, 2.86, 11.42, 15.23 and $4.76 \mathrm{ng} \mathrm{m}-3$ in Dhaka (Farmgate), Noakhali, Chittagong, Faridpur and Kustia, respectively (Table III) (between October to December 2011) during the dry months. The total average of $\mathrm{Cd}$ in Dhaka air was $13.00 \mathrm{ng}$ $\mathrm{m}-3$ as reported by Salam et al., (2008). On the other hand, the total average of $\mathrm{Cd}$ concentration at motijheel, Dhaka air was very close (4.46 ng m-3) to the WHO guideline value of $5.00 \mathrm{ng}$ m-3 as reported by Salam and co-workers
(Salam and Salam (2011). In this study, the daily average concentration of $\mathrm{Cd}$ in atmospheric aerosol exceeded the WHO guideline value in five city areas of Bangladesh. The higher cadmium concentration in Dhaka, Chittagog and Faridpur air may be due to the release of $\mathrm{Cd}$ from different industrial mechanical processes inside the city (battery, electroplating, metal refining industries etc.). However, it is lower than that reported for Southeast Asian sites such as Laore, Pakistan (43.50 ng m-3) (Smith et al., 1996) and Bombay (40.00 ng m-3 ) (Sharma and Patil, 1992), India.

Table I: Average Suspended Particulate Matter in Air $(\mu \mathrm{g} / \mathrm{m3})$

\begin{tabular}{|c|c|c|c|}
\hline District & SPM & Year/Period & References \\
\hline All values for $8 \mathrm{hrs}$ & $\mu \mathrm{g} / \mathrm{m} 3$ & of AQ Monitoring & \\
\hline Farmgate, Dhaka & 413.02 b & 2011 & (Current study) \\
\hline Dhaka (av) & $126-523(\mathrm{av}-263)$ & 2006 & Salam et al., 2008 \\
\hline Dhaka (av) & $206-636(385.3( \pm 21)$ & 2008 & Rahman et al., 2013 \\
\hline Dhaka & $665-2456$ & & Core, 1998 \\
\hline Karachi Bazar, Noakhali & $292.63 \mathrm{~d}$ & 2011 & (Current study) \\
\hline Alfalah Housing Soetity, Khulshi, Chittagong & 671.65 a & 2011 & (Current study) \\
\hline Chittagong & $172-904$ & & $\mathrm{ADB}, 2006$ \\
\hline Chittagong & 1172-2432(av. 1510) & 2008 & Jamaluddin and Khorshed, 2012 \\
\hline Chittagong & 658-2254(av. 1602) & 2008 & Jamaluddin et al., 2012 \\
\hline Faridpur medical College, Faridpur & $184.09 \mathrm{e}$ & 2011 & (Current study) \\
\hline Daulotpue, Kustia & 301.13 c & 2011 & (Current study) \\
\hline Bogra & $170-531$ & 2004 & ADB, 2006 \\
\hline Rajshshi & $329-680$ & 2003 & $\mathrm{ADB}, 2006$ \\
\hline Sirajgonj & $400-420$ & 2004 & ADB, 2006 \\
\hline \multirow[t]{2}{*}{ Pabna } & $500-829$ & & $\mathrm{ADB}, 2006$ \\
\hline & $8 \mathrm{hrs}$ & - & \\
\hline \multirow[t]{3}{*}{ WHO standard } & $24 \mathrm{hrs}$ & $150-230$ & WHO, 2005 \\
\hline & annual & $60-90$ & \\
\hline & $8 \mathrm{hrs}$ & - & \\
\hline \multirow[t]{3}{*}{ US standard } & $24 \mathrm{hrs}$ & 150 & \\
\hline & annual & 50 & \\
\hline & $8 \mathrm{hrs}$ & 200 & \\
\hline \multirow[t]{2}{*}{ Bangladesh standard } & $24 \mathrm{hrs}$ & - & (Calastrini et al., 1997) \\
\hline & annual & - & \\
\hline
\end{tabular}




\section{Copper (Cu) concentration:}

The daily average concentration of copper was the highest in October to December, 2011, in Chittagong (801.26 $\mathrm{ng} / \mathrm{m} 3$ ) and the lowest in Faridpur (68.60 ng/m3) city of Bangladesh (Table III). The copper concentration in SPM of the city ambient air were 248.67, 666.90, 801.26, 68.60, $342.03 \mathrm{ng} / \mathrm{m} 3$, respectively in Dhaka, Noahkali, Chittagong, Faridpur and Kustia, respectively. Due to seasonal variation trace metal concentration in the atmospheric aerosol vary significantly. $\mathrm{Cu}$ exhibited the industrial areas constitute a significant part of the traffic and the combination of the hilly nature of the area, the stop and start mode of the congested traffic and the age and heavy loading of most of the trucks causes large emissions of black diesel smoke. Brick kilns are an important source of building materials and pollution. Prior work in Dhaka, the capital city of Bangladesh, has suggested a major role for brick kilns in providing air pollution (Begum et al., 2013).

Table II: Proposed AQI (Air Quality Index) for Bangladesh and the place of city areas of Bangladesh according to the current study

\begin{tabular}{llll}
\hline AQI Range & Category & Color & District \\
\hline 0 to 100 & Good & Green & - \\
101 to 200 & Unhealthy & Orange & Faridpur (This study) \\
201 to 300 & Very Unhealthy & Purple & Noakhali (This study) \\
$>301$ & Extremely Unhealthy & Red & Chittagong, Dhaka, Kustia (This study) \\
$>301$ & Extremely Unhealthy & Red & Bogra, Rajshahi, Sirajgong and Pabna (ADB, 2006) \\
\hline
\end{tabular}

Source: Air Quality Management Project, 2003.

higher concentration value among the measured value reported before for Dhaka, except Chittagong. However, it is lower than that reported for Southeast Asian sites such as Lahore, Pakistan (420.00 ng m-3) (Smith et al., 1996), Mumbai (290.00 ng m-3 ) (Sharma and Patil, 1992), India and Calcutta, India (112.00 ng m-3 ) (Chatterjee et al., 1988). The increasing trend of $\mathrm{Cu}$ concentration $(95.00 \mathrm{ng}$ m-3 for PM2.5) was measured in 2006 by Salam et al., (2008) which was about two fold higher than the value (54.00 ng m-3 for SPM) obtained by Salam et al., (2003). $\mathrm{Cu}$ concentrations in five city areas of Bangladesh in this study were higher than the European cities as well as the cities of USA (Table III).

Chittagong city is the most populated cities in Bangladesh, reported by Jamaluddin and co-workes (Jamaluddin et al., 2012). In this study $\mathrm{Cu}$ concentration was $801.29 \mathrm{ng} \mathrm{m}-3$ (in October to December, 2011) which was lower than the value measured at different locations in Chittagong (Jamaluddin et al., 2012). Chittagong is the second largest city and 'Commercial Capital' of Bangladesh. The main road network in the city goes toward the port area and northward toward the industrial areas. These roads are also congested, with persistent traffic jams most of the day. Trucks transporting goods between the port and the

\section{Zinc ( $\mathrm{Zn})$ concentration:}

The average $\mathrm{Zn}$ concentration in Dhaka was reported earlier by many investigators $911.00 \mathrm{ng}$ m-3 (Mahmud et al., 2008) and $801.00 \mathrm{ng} \mathrm{m-3} \mathrm{(Salam} \mathrm{et} \mathrm{al.,} \mathrm{2003).} \mathrm{In} \mathrm{this} \mathrm{study,}$ $\mathrm{Zn}$ concentration in the total suspended particulate matter in five city areas of Bangladesh were 860.81, 405.56, 1721.60, 557.31 and 598.81 ng m-3 in Dhaka, Noakhali, Chittagong, Faridpur and Kustia, respectively. All values are lower than Mumbai, India but higher than Lahore, Pakistan, Calcutta, India (Table III) as well as the cities of Europe and USA.

The concentration of $\mathrm{Zn}$ in Dhaka city air during 2007-2009 ranged from $44.70-8087 \mathrm{ng} / \mathrm{m} 3$ reported by Begum et al., (2013) and Chittagong air was 329.60-415.39 $\mu \mathrm{g} / \mathrm{m} 3$ i.e. $3.29 \times 10-5-4.15 \times 10-5 \mathrm{ng} / \mathrm{m} 3$ (Jamaluddin et al., 2012). The air of Chitttagong city is highly polluted. As a divisional headquarters, port city and commercial capital city, the rate of urbanization is high in Chittagong metropolitan city. The impact of large influx of population in the city has been quite strong on the overall environmental situation in the city. The municipal authority should take a lead in organizing a concerted and coordinated effort with other governmental and non-governmental agencies in solving the problem of the city as soon as possible. The community 
people should also be mobilized in such efforts because people's participation is very much fruitful in improving the environmental situation (Jamaluddin et al., 2012).

\section{Conclusion}

The city areas of Bangladesh are found to be highly polluted and fall in the "unhealthy to extremely unhealthy class" according to Air Quality Management Project, (2003). The study reveals that the status of air pollution was found to very critical. The rapid urban development that has

Table III: Comparison of trace metals levels at city areas of Bangladesh and other International studies

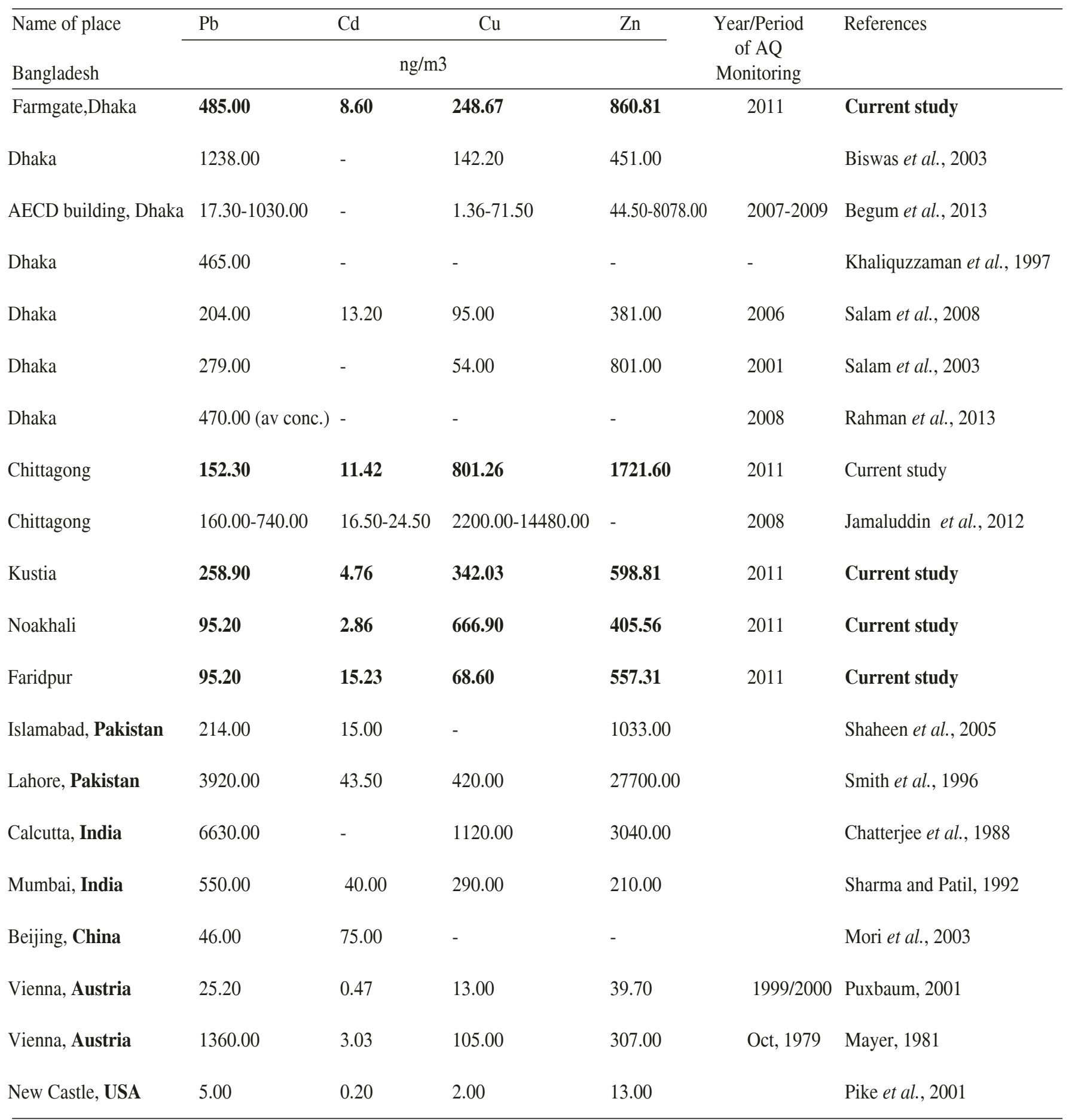


occurred and is on going in Dhaka is also occurring in Chittagong, Kustia, Noakhali and Faridpur. The average results of trace metals have been compared to national and international standards. The trace metal concentration of current study has been compared with different cities in the world in Table III.

\section{Acknowledgement}

We are indebted to the Chairman, department of Soil, Water and Environment, University of Dhaka for providing the instruments for collection of the samples and the generous help and permission for using Atomic Absorption Spectrophotometer for analyses of the samples.

\section{References}

Anomymous, ADB (Asian Development Bank). (2006), Country Synthesis Report on Urban Air Quality Management, Bangladesh. Key Indicators. ADB. Manila. Available at: WWW.adb.org/documents/book/key_indicators/ 2006/default.asp.

Ahammad Sk. S., Shajhan Siraj, Md. Sabder Ali, Md. Azizul Kaji and Feroz Kabir Kazi. (2010), Tracking of possible sources of Dhaka city air pollutants. Proc. Of International Conference on Environmental Aspects of Bangladesh (ICEAB10), Japan, Sept.2010.

Ahmed F. and Ishiga H. (2006), Trace metal concentrations in sreet dusts of Dhaka city, Bangladesh. Atmos. Environ. 40:3835-3844.

Anomymous, Air Quality Management Project (AQMP). (2003), Inter Ministerial Committee Meeting. Working paper 3 - proposed Air Quality Indes (AQI) for Dhaka. Department of Environment. August. Bangladesh.

Begum Bilkis A, Philip K. Hopke and Andreas Markwitz. (2013), Air pollution by fine particulate matter in Bangladesh. Atmosperic Pollution Research. 4: 75-86.

Biswas, S.K., Tarafdar, S.A., Islam, A., Khaliquzzaman, A., Tervahattu, H. and Kupiainen, K. (2003), Impact of unleaded gasoline introduction on the concentration of lead in the air of Dhaka, Bangladesh. J. Air \& Waste Manag. Assoc. 53: 1355-1362.

Borbely-kiss, I E Koltay, G Y Szabo, L Bozo, K.Tar. (1999), Composition and sources of urban and rural atmospheric aerosol in Eastern Hungary. J. Aerosol Sci. 30: 369-391.
Chatterjee D, van Vaeck L. and van Espen P. (1988), Calcutta pollutants: Part 2. Polynuclear aromatic hydrocarbons and some metal concentrations on air particulates during winter 1984. Intern. J. Environ. Ana. Chem. 32: 109-120.

Core J. (1998), Sources of air pollution and and control options. Paper presented in the Consultative Meeting of World Bank and DoE. Government of Bangladesh, Dhaka.

Jamaluddin A. M., and Khorshed A. (2012), Int. J. Res. Chem. Envirom. 2(2): 178-187.

Jamaluddin A. M., Khorshed A. M., Hossain M., Siraj S. and Ahsan M. A. (2012), Determination of trace metals in air of Chitagong city-Bangladesh. European J. Chemistry. 3(4): 416-420.

Khaliquzzaman M, Biswas S K, Tarafdar S A, Islam A, Khan A H. (1997), Trace element composition of size fractionated airborne particulate matter in urban and rural areas of Bangladesh. Report AECD/AFD-CH:6-4.

Puxbaum H. (2001), Austrian Project for the Health Effect of Particulate Matters (AUPHEP).

Rahman M A, Abdur Rahim, Nur-E-Alam Siddique and Shafiqul Alam A M. (2013), Studies on selected metals and other pollutants in urban atmosphere in Dhaka, Bangladesh. Dhaka Univ. J. Sci. 61(1): 41-46.

Ramanathan V, and P Crutzen, (2003), Atmospheric Brown "Clouds". Atmospheric Environment. 37: 4033-4035.

Salam A, Bauer H, Kassin K, Ullah SM and Puxbaum H. (2003), Aerosol chemical characteristics of a mega-city in Southeast Asia (Dhaka, Bangladesh\}. Atoms Environ. 37: 2517-2528.

Salam A., Tofazzal Hossain, M. N. A. Siddique and A. M. Shafiqul Alam. (2008), Characteristics of atmospheric trace gases, particulate matter and heavy metal pollution in Dhaka, Bangladesh. Air Quality, Atmosphere \& Health.

Salam Abdus and Md Abdus Salam. (2011), Levels of trace metals in atmospheric suspended particulate matters in Dhaka, Bangladesh. Bangladesh Pharmaceutical journal. 14(1): 21-26. 
Salam Abdus, Tofazzal Hossain, M. N. A. Siddique and A. M. Shafiqul Alam. (2008), Characteristics of atmospheric trace gases, particulate matter, and heavy metal pollution in Dhaka, Bangladesh. Air Qual Atmos Health.1: 101-109.

Sharma V K and Patil R S. (1992), Chemical composition and source identification of Bombay aerosol. Environ Technol. 13: 1043-1052.

Smith D J T, Harrision R M, Luhana L, Casimiro P, Castro L M, Tariq M N. (1996), Concentrations of particulate airborne polycyclic aeromatic hydrocarbon and metals collected in Lahore, Pakistan. Atoms Environ. 30: 4031-4040.
Wahid, A. (2006). Productivity losses in barley attributable to ambient atmospheric pollutants in Pakistan. Atmospheric Environment,. 40(28), 5342-5354.

Anomymous, WHO (World Health Organization). (2005), WHO air quality guideline update. Report of the working group meeting. WHO, Bonn, Germany.

Received: 12 March 2014; Revised: 20 August 2014 Accepted: 25 August 2014 